Maurer School of Law: Indiana University

Digital Repository @ Maurer Law

2015

\title{
The Role of Agency: Compensated Surrogacy and the Institutionalization of Assisted Reproduction Practices
}

Jody L. Madeira

Indiana University Maurer School of Law, jmadeira@indiana.edu

June Cabone

University of Minnesota Law School

Follow this and additional works at: https://www.repository.law.indiana.edu/facpub

Part of the Medical Jurisprudence Commons, and the Science and Technology Law Commons

\section{Recommended Citation}

Madeira, Jody L. and Cabone, June, "The Role of Agency: Compensated Surrogacy and the Institutionalization of Assisted Reproduction Practices" (2015). Articles by Maurer Faculty. 1952.

https://www.repository.law.indiana.edu/facpub/1952

This Article is brought to you for free and open access by the Faculty Scholarship at Digital Repository @ Maurer Law. It has been accepted for inclusion in Articles by Maurer Faculty by an authorized administrator of Digital Repository @ Maurer Law. For more information, please contact rvaughan@indiana.edu. 


\title{
THE ROLE OF AGENCY: COMPENSATED SURROGACY AND THE INSTITUTIONALIZATION OF ASSISTED REPRODUCTION PRACTICES
}

\author{
June Carbone* and Jody Lyneé Madeira**
}

\begin{abstract}
The surrogacy debate often conflates what should be seen as three distinct issues: the permissibility of the practice under any circumstances, the role of for-profit intermediaries in arranging surrogacy, and the role of compensation in influencing decisionmaking.

For those who see surrogacy as intrinsically objectionable, nothing short of a total ban will suffice. For those who object to the commodification of reproduction or to the role of for-profit agencies in recruiting surrogates, however, the solutions lie in regulation rather than prohibition. Commercial agencies, unlike infertile couples who enter into arrangements with their friends and relatives, are repeat players. They are in a better position to institutionalize appropriate practices and instantiate acceptable norms than are parties driven by the desire to produce a child.

We conclude that much of the objection to commercial surrogacy involves the practice's growing pains. In the end, commercial agencies, particularly if they are subject to regulations that require transparency and provide oversight, may promote human dignity as well as, or better than, individually negotiated altruistic arrangements.
\end{abstract}

\section{INTRODUCTION}

The surrogacy ${ }^{1}$ debate often conflates what should be seen as three distinct issues: the permissibility of the practice under any circumstances, the role of for-profit intermediaries in arranging surrogacy, and the role of compensation in influencing decision-making. While some find surrogacy intrinsically objectionable, most are troubled instead by reproductive commodification and the role of for-profit

* Robina Chair in Law, Science and Technology, University of Minnesota Law School.

** Professor of Law, Indiana University Maurer School of Law.

1. Surrogacy refers to the practice whereby a woman gives birth to a child with the intention that the child will be raised by someone else. Modern assisted reproduction technology (ART) makes two different types of surrogacy possible. With "traditional surrogacy," artificial insemination is used to fertilize the egg inside the woman's body with the intended father's sperm. In these cases, the surrogate mother is the genetic and the gestational mother to the resulting child. With gestational surrogacy, doctors fertilize an egg either from the intended mother or from a donor with a man's sperm and implant the fertilized egg in the womb of a woman who gives birth to the child. In these cases, the gestational surrogate has a "biological” relationship to the child through gestation, but no genetic tie to the child. See Pamela Laufer-Ukeles, Mothering for Money: Regulating Commercial Intimacy, 88 IND. L.J. 1223, 1260 (2013). 
agencies in arranging the practice. We contend that much of the objection to commercial surrogacy is a response to the practice's growing pains. Any new technology, particularly one as controversial as surrogacy, involves the creation of new procedures and appropriate norms. Commercial agencies, unlike infertile couples who arrange for the use of sisters or friends to give birth to their children, are repeat players. Thus, they are more likely to routinize the practice; provide screening; shape the parties' understandings; and, for all intents and purposes, fix prices. In the end, commercial agencies may promote human dignity as well as, or better than, individually negotiated altruistic arrangements. Accordingly, we maintain that prohibitions on payment obstruct, rather than enhance, the development of socially acceptable surrogacy arrangements.

In this Essay, we examine the relationship between the development of surrogacy and the commercialization of assisted reproduction. First, we review the intrinsic objections to surrogacy and show that they are strongest in the context of "traditional surrogacy," where the surrogate mother gives birth to her genetic child for transfer to another. Second, we discuss the objections to "gestational surrogacy," where the woman who gives birth is bearing a child to whom she is not genetically related, and demonstrate that the most forceful of these objections do not involve intrinsic objections to surrogacy itself. Rather, these objections implicate the process of commodification. Third, we maintain that the criticisms of commodification that involve fears of exploitation apply to altruistic as well as commercial surrogacy. Finally, we conclude that for-profit agencies, if administered with transparency and accountability, contribute to the development of an appropriate ethical infrastructure for surrogacy decision-making to a greater degree than exclusive reliance on altruistic transactions.

\section{THE ACCEPTABILITY OF TRADITIONAL AND GESTATIONAL SURROGACY}

Surrogacy - the practice of having a woman give birth to be raised by another-has existed since antiquity. In the book of Genesis, Abraham's infertile wife, Sarah, persuaded her handmaid, Hagar, to give birth to Abraham's child, whom Abraham and Sarah raised as their own. ${ }^{2}$

2. Christine L. Kerian, Surrogacy: A Last Resort Alternative for Infertile Women or a Commodification of Women's Bodies and Children?, 12 WIS. Women's L.J. 113, 116-117 (1997) (noting that Sarah persuaded Abraham to sleep with Hagar to produce the child. In addition, Rachel, Jacob's infertile wife, similarly arranged for her maid Bilhah to have a child that Jacob and Rachel raised). 
Today, we would call that process "traditional surrogacy," except that the woman giving birth would become pregnant through artificial insemination rather than intercourse. ${ }^{3}$ Since the advent of in vitro fertilization (IVF) in the 1970's, however, a man's sperm can fertilize a woman's egg outside the body and then be implanted into a second woman who will ultimately give birth to the child. ${ }^{4}$ This process, called "gestational surrogacy," allows a woman to give birth to a child to whom she was not genetically related. ${ }^{5}$

The separation of genetics and gestation gives rise to two different types of objections to surrogacy. The first objection focuses on the transfer from the mother to another family, and is criticized as "baby selling." ${ }^{6}$ The second objection involves the use of the surrogate's gestational services to give birth, and is criticized as "womb rental."7 Critics of traditional surrogacy combine both arguments. Those who object to gestational surrogacy focus on the second objection. In this section, we argue that the opposition to traditional surrogacy tends to be a wholesale opposition to the practice in any form, but that the criticisms of gestational surrogacy are more likely to concern specific practices that are not necessarily intrinsic to surrogacy itself.

Surrogacy first captured popular attention in the late 1980's with the birth of Melissa Stern, the infamous "Baby M.", In this much publicized case, Herbert Stern, the only child of Holocaust survivors, was married to Elizabeth Stern, a doctor who suffered from multiple sclerosis and who feared that pregnancy would worsen her condition. ${ }^{9}$ Mr. Stern, determined to have a biologically-related child, entered into a contract with Mary Beth Whitehead to bear a child for him. ${ }^{10}$ Whitehead would be the genetic and gestational mother of the child. According to the New

3. Amanda Mechell Holliday, Who's Your Daddy (and Mommy)? Creating Certainty for Texas Couples Entering Into Surrogacy Contracts, 34 TEX. TECH. L. REV. 1101, 1102 (2003).

4. Id. at 1103.

5. Id. at $1102-1103$.

6. See generally Nancy M. Machinton, Surrogate Motherhood: Boon or Baby Selling? The Unresolved Questions, 71 MARQ. L. REV. 115 (1987).

7. See, e.g., Melody Chen, Wombs for Rent: An Examination of Prohibitory and Regulatory Approaches to Government Preconception Arrangements, 23 HEALTH LAW IN CAN. 33 (2003); Julie Bindel, Commercial Surrogacy is a Rigged Market in Wombs for Rent, THE GuARDIAN, Feb. 20, 2015, http://www.theguardian.com/commentisfree/2015/feb/20/commercial-surrogacy-wombs-rentsame-sex-pregnancy.

8. Elizabeth S. Scott, Surrogacy and the Politics of Commodification, 72 LAW \& CONTEMP. PROBS. 109, 112-13 (2009).

9. In re Baby M, 537 A.2d 1227, 1235 (N.J. 1988).

10. Id. 
Jersey Supreme Court, she would also be the child's legal mother. ${ }^{11}$

Baby $M$ touched off a firestorm of publicity and condemnation. Criticisms combined two concerns: the specter of "baby selling" (a mother being paid to create to create a child for another) ${ }^{12}$ and fear of exploitation (a belief that a mother would do this only because money overcame more sensible judgments). ${ }^{13}$ The two concerns were related. During this time, IVF was in its infancy. Surrogates, who were artificially inseminated with the intended father's sperm, provided both the egg and the womb.

More than twenty-five years after Baby $M$, surrogacy remains controversial. A minority of commentators objects to surrogacy altogether, some would permit it in limited circumstances (allowing, for example, the use of a gestational carrier to give birth to the genetic child of a woman born without a womb), and still others would leave the matter entirely to individual choice. ${ }^{14}$ For those who find surrogacy or particular surrogacy-related practices intrinsically objectionable, the only solution is a ban on the offensive practices, whether or not the surrogate is paid. Yet, the effect of gestational surrogacy has been to separate the arguments against all surrogacy from those opposed to traditional surrogacy per se.

Conceiving a child and carrying it to term is an act of creation and profound psychological bonding. Many view reproduction as an act of wonder; religions view it as sacred. Moreover, for most women, pregnancy involves an adjustment to the idea of motherhood. Over the course of the pregnancy, hormonal fluctuations produce intense mood swings and most women experience an intensifying identification with their child as they work through the cascade of pregnancy-related emotions. Pregnancy gives prospective mothers a chance to prepare for the birth, and most behold the children they produce with awe and joy. Accordingly, while all pregnant women experience physical and emotional changes, traditional surrogacy asked a mother to surrender her child immediately after birth, where a new mother is ordinarily expected to feel an extraordinarily intense identification with the child she has

11. Id

12. Id.; see also Margaret Jane Radin, What, If Anything, Is Wrong with Baby Selling?, 26 PAC. L.J. 135, 144-45 (1995).

13. See Iver Peterson, Baby M, Ethics and the Law, N.Y. TIMES, Jan. 18, 1987, http://www.nytimes.com/1987/01/18/nyregion/baby-m-ethics-and-the-law.html ("To some who have studied the issue one of the most disturbing elements of surrogate motherhood is the overtone of class exploitation.").

14. See infra notes 15-23. 
produced. ${ }^{15}$

Some religious and secular philosophers maintain that surrogacy is intrinsically impermissible whether compensated or not. The Catholic Church's modern theology of the body, for example, associates the divine - and human dignity — with the conception of a child within a woman's body as a result of intercourse, celebrating the unity of sex, marriage, and procreation as part of God's plan. ${ }^{16}$ Accordingly, the Church objects not only to surrogacy, compensated or unpaid, but to IVF altogether. ${ }^{17}$ Secular philosophers, such as Immanuel Kant, maintain that human beings should always be seen as ends in themselves, not means to an end. ${ }^{18}$ Religious and secular traditions disfavor the creation of a child for a reason other than the desire for the child itself. Surrogacy involves conception not for the child's sake or as the natural outcome of sexual intercourse, but for other reasons. Payment compounds the offense, but the same objection would apply if the mother's motive were to please a third party. The child becomes a means by which the mother achieves ends that may not necessarily involve the child at all. Even if the mother has confidence in the prospective parents' love and ability to provide for the child, she still has given birth to a human being who would not exist but for payment or for the mother's sense of obligation to another. In accordance with this line of thinking, traditional surrogacy is necessarily objectionable because the mother creates the child for another.

15. See, e.g., Brief of Organizations Committed to Women's Equality as Amici Curiae in Support of Respondents at 9, Ayotte v. Planned Parenthood of Northern New England, 546 U.S. 320 (2006) (No. 04-1144) ("While the lasting impact of bearing a child could be mitigated by surrendering the child to others to raise, in reality, fewer than one percent of children born to nevermarried women are placed for adoption.... This likely reflects the psychological toll of giving up a child at birth.”).

16. See, e.g., United States Conference of Catholic Bishops, Ethical and Religious Directives for Catholic Health Care Services 24 (5th ed. 2009), available at http://www.ncbcenter.org/ document.doc?id=147 ("Reproductive technologies that substitute for the marriage act are not consistent with human dignity. Just as the marriage act is joined naturally to procreation, so procreation is joined naturally to the marriage act.").

17. See, e.g., Donum Vitae, available at http://www.vatican.va/roman_curia/congregations/ cfaith/documents/rc_con_cfaith_doc_19870222_respect-for-human-life_en.html (determining both heterologous and homologous artificial fertilization to be unacceptable); John M. Haas, Begotten Not Made: A Catholic View of Reproductive Technology, U.S. CONFERENCE OF CATHOLIC BISHOPS, http://www.usccb.org/issues-and-action/human-life-and-dignity/reproductive-technology

/begotten-not-made-a-catholic-view-of-reproductive-technology.cfm (last visited Mar. 30, 2015) ("One reproductive technology which the Church has clearly and unequivocally judged to be immoral is in vitro fertilization or IVF.").

18. See Immanuel Kant, The Metaphysics of Morals 186-87 (Mary Gregor ed., 1996); Martha C. Nussbaum, Women and Human Development: The Capabilities Approach 73 (2000) (stating that the Kantian notion of dignity requires recognizing "each person [as] a bearer of value" and views exploitation as treating "a person as a mere object for the use of others.”). 
By contrast, philosophers disagree about gestational surrogacy, which involves appropriation of the surrogate's labor without use of her genetic material. Thus, it does not include her involvement in the child's conception. ${ }^{19}$ Exacerbating the more abstract concerns is the mother's relinquishment of the child to the prospective parents. ${ }^{20}$ Cultural mores stress that a mother is supposed to experience a profound connection to her newborn, and that giving up that child should be wrenching. Handing over a child is a form of abandonment, even betrayal. Accordingly, surrogacy, to the extent it involves the deliberate creation of a child for another, victimizes both the mother who surrenders a child and that child, who may wonder why her mother intentionally gave her up. ${ }^{21}$ While gestation itself creates a sense of attachment to the child (and some will also object to gestational surrogacy on this ground), the normative conclusion that the traditional surrogate should identify and bond with the child is reinforced by the sense that the child is intrinsically and uniquely "hers."

Complementing the harm to the mother is the emotional dissonance authorities may feel in enforcing surrogacy agreements when they go awry. Mary Beth Whitehead fled, for example, rather than surrender the child to the Sterns. ${ }^{22}$ When the police eventually confronted her, they forcibly took the baby and returned it to the Sterns. ${ }^{23}$ Enforcing surrogacy contracts, as in Baby $M$, may require literally taking a baby from its mother's arms. The prospect is disturbing not only because of the potential impact on mother and child, but also because it involves state intervention to sever a maternal connection.

At the time of Baby $M$ and afterwards, others have argued that women were fully capable of making surrogacy arrangements. ${ }^{24}$ Women, like men who have one-night stands or donate to a sperm bank, should be able to decide to create a child they will not raise. Responsible women who elect to enter into surrogacy contracts may want assurances that new parents will adequately provide for the child, but they should not be

19. For a definition of gestational surrogacy, see supra note 5 and accompanying text. For discussion of the ethical distinctions between traditional and gestational surrogacy as they relate to the meaning of motherhood, see infra notes 31-39 and accompanying text.

20. See, e.g., Ellen Goodman, Surrogates Could Make Pregnancy a Service Industry, L.A. TIMES, Sept. 2, 1986, at B5 ("I do not believe that anyone should be able to sign away parental rights before she has even borne the child. A baby is not a piece of goods, and human emotions do not make for neat contracts.”).

21. For a summary of these arguments, see Scott, supra note 8, at 112.

22. In re Baby M, 537 A.2d 1227, 1235 (N.J. 1988).

23. Id. at $1236-37$.

24. See Iver Peterson, Baby M Trial Splits Ranks of Feminists, N.Y. TIMES, Feb. 24, 1987, at B2. 
subject to motherhood ideals that assume that all women identify with all of their genetic offspring in particular ways. Just as some object to state intervention in taking a newborn away from its mother, so do others object to state intervention that limits reproductive choices. ${ }^{25}$ These individuals argue that no option, including reproductive surrogacy, should be taken off the table. ${ }^{26}$

However, these arguments, which address women's decision-making capacity, do not respond to arguments rooted in the personhood of the child. ${ }^{27}$ The latter arguments involve societal judgments about the identity of parenthood, and traditional surrogacy involves production of a child who, in every sense but parental intent, is the child of the traditional surrogate. The appropriate response to objections that surrogacy intrinsically dehumanizes the child is to ban traditional surrogacy altogether or to limit it to narrow circumstances where the birth mother's genetic tie to the child is important in itself. ${ }^{28}$

\section{GESTATIONAL SURROGATES AND THE PROSPECT OF EXPLOITATION}

The development of gestational surrogacy fundamentally changed the nature of the surrogacy debate. A substantial basis for the objections to surrogacy in Baby $M$ focused on the ties between the child and a mother who both supplies an egg and gives birth. ${ }^{29}$ In contrast, objections to gestational surrogacy depend less on the mother-child tie and more on the potential for abuse of the relationship between the intended parents and the carrier. ${ }^{30}$ This section will focus on three types of objections: first, the degree to which use of a woman's reproductive capacity for another can be reconciled with notions of human dignity; second, the

25. See, e.g., Calvert v. Johnson, 851 P.2d 776, 785 (Cal. 1993) (“The argument that a woman cannot knowingly and intelligently agree to gestate and deliver a baby for intending parents carries overtones of the reasoning that for centuries prevented women from attaining equal economic rights and professional status under the law.”).

26. See, e.g., Lorraine Sorrel, Baby M Again, OfF Our BACKS, July 31, 1987, at 26.

27. Margaret Jane Radin, Market-Inalienability, 100 HARV. L. REV. 1849, 1928-36 (1987) (discussing how commodification affects personhood).

28. The most typical cases will involve sisters or other relatives who share a genetic link with the intended mother. There is, however, another set of concerns tied to the woman's health. Artificial insemination is, after all, a relatively non-intrusive process. Use of in vitro fertilization, on the other hand, is necessary for a woman to give birth to another woman's child and it involves far more risk to the gestational carrier. See discussion infra, p. 11.

29. See supra notes 20-22 and accompanying text.

30. See Michelle Ford, Gestational Surrogacy Is not Adultery: Fighting Against Religious Opposition to Procreate, 10 BARRY L. REV. 81, 98-99 (2008). 
gestational carrier's decision-making capacity in light of the physiological and psychological impact of pregnancy; and third, the acceptability of the health risks to the carrier.

The fundamental difference between traditional and gestational surrogacy is that the woman who gives birth is not the child's genetic parent. IVF, which creates the ability to fertilize a woman's eggs outside the body and transfer the developing embryos into another woman, ${ }^{31}$ makes it possible to separate the gestational and genetic aspects of parenthood. It also raises a question that women have never had to face before: what makes a person a mother?

Law professor Gary Spitko advances a "labor theory" of parenthood that would treat the gestational mother as the initial legal parent, regardless of the circumstances of conception. ${ }^{32}$ His theory recognizes a second legal parent (including a genetic father) only with the gestational mother's consent. ${ }^{33}$ Accordingly, gestational and traditional surrogates would be treated as legal parents absent their post-birth consent to adoption. Some state laws are in accord with this theory, recognizing the woman who gives birth as a legal parent on the basis of her gestational role. ${ }^{34}$ Other states, however, even if they would ordinarily regard the gestational mother as a legal parent, permit a pre-conception judicial proceeding (with adoption-like safeguards) to secure the intended parents' legal parentage at birth. ${ }^{35}$

The majority of states reject the privileging of gestation over the genetic connection. These states stress intent to parent the child as the most important factor, and refuse to accord surrogates a parental status equivalent to the infertile couple. In the first major gestational surrogacy decision, Johnson v. Calvert, the California Supreme Court ruled explicitly that intent was the tie breaker between two women who each had a biological tie to the child. ${ }^{36}$ In that case, Christina Calvert was

31. See In vitro fertilization (IVF) Definition, MAYO CLINIC, http://www.mayoclinic.org/testsprocedures/in-vitro-fertilization/basics/definition/prc-20018905 (last visited Mar. 25, 2015).

32. E. Gary Spitko, The Constitutional Function of Biological Paternity: Evidence of the Biological Mother's Consent to the Biological Father's Co-Parenting of Her Child, 48 ARIZ. L. REV. 97 (2006).

33. Id. at 104.

34. See, e.g., Perry-Rogers v. Fasano, 715 N.Y.S.2d 19, 23, 24 (2000) ("It is apparent from the foregoing cases that a 'gestational mother' may possess enforceable rights under the law, despite her being a 'genetic stranger' to the child.").

35. See Brock A. Patton, Buying a Newborn: Globalization and the Lack of Federal Regulation of Commercial Surrogacy Contracts, 79 UMKC L. REV. 507, 518-20 (2010) (summarizing state laws).

36. Johnson v. Calvert, 851 P.2d 776 (Cal. 1993). 
unable to carry a child to term, and Anna Johnson agreed to give birth to a child conceived with Christina's egg and her husband's sperm. When Johnson contested parentage after the child's birth, the court ruled that, under California's version of the Uniform Parentage Act, both the genetic mother and the gestational carrier could be recognized as parents. Rather than privilege either genetics or gestation, the court held that intent plus either genetics or gestation determined parentage. ${ }^{37}$ It accordingly recognized Calvert as the legal mother. ${ }^{38}$

Since Johnson v. Calvert, the majority of gestational surrogacy cases have deferred to the parties' intent. ${ }^{39}$ The principal statutory exceptions have come from states that would either discourage surrogacy ${ }^{40}$ or recognize the woman giving birth as the mother. ${ }^{41}$ The latter encourage use of judicial process to determine parenthood. ${ }^{42}$ Even then, state courts in Utah and Florida have held such statutes unconstitutional to the extent they preclude legal recognition of a genetic parent using a gestational carrier with the intention of retaining her parental status. ${ }^{43}$ Whether or not these cases produce ironclad constitutional guarantees, the weight of authority favors consideration of the combination of intent and genetics over gestation alone. Thus, the labor theory, in its pure form, has not been credited in most jurisdictions.

The conclusion that the child belongs to the intended parents frames the objections to and the defenses of gestational surrogacy. The first concern is that the intended parents are using another person, not as an equal partner in their efforts to create a child, but as a means to an end. They are thus appropriating the fruits of the gestational carrier's labor,

37. Id. at 782 .

38. Id. ("We conclude that although the Act recognizes both genetic consanguinity and giving birth as means of establishing a mother and child relationship, when the two means do not coincide in one woman, she who intended to ... bring about the birth of a child that she intended to raise as her own-is the natural mother under California law.”).

39. See Scott, supra note 8, at 110 n.11. See also Mary Patricia Byrn \& Lisa Giddings, An Empirical Analysis of the Use of the Intent Test to Determine Parentage in Assisted Reproductive Technology Cases, 50 Hous. L. REV. 1295, 1297 (2013) (observing that courts generally defer to intent in cases involving assisted reproduction).

40. See, e.g., Мich. Comp. LaWs AnN. § 722.857 (West 2013); N.Y. Dom. Rel. LaW AnN. $\S 123$ (McKinney 2013).

41. See, e.g., UnIF. PARENTAGE Act § 201(a)(1), 9B U.L.A. 362 (2001 \& Supp. 2012).

42. Id. See also TeX. FAm. Code ANN. § 160.755 (Vernon Supp. 2008) (requiring judicial proceeding); UtAH Code ANN. §§ 78B-15-803 (Supp. 2008); VA. CodE ANN. § 20-160(A)(B) (2008); N.H. Rev. StAT. AnN. § 168-B:16, B:20, B:22-23 (LexisNexis 2004 \& Supp. 2008).

43. J.R. v. Utah, 261 F. Supp. 2d 1268, 1296 (D. Utah 2002); D.M.T. v. T.M.H., 129 So. 3d 320

(Fla. 2013) (invalidating refusal to recognize genetic mother as legal parent to child born to her same-sex partner). 
without crediting her investment in the child's birth. ${ }^{44}$ Payment increases the concern. A friend or relative might enter into a surrogacy arrangement as an equal in a relationship of mutual respect. Intended parents, on the other hand, are more likely to reduce a commercial surrogate's contribution to the price of the contract.

In fact, surveys of commercial surrogacy in the United States belie the claim that gestational carriers feel that surrogacy arrangements are intrinsically unfair or demeaning. These surveys indicate that gestational carriers are motivated at least in part by the desire to help others to conceive. ${ }^{45}$ While carriers might not agree to undertake pregnancy's considerable inconvenience and expense absent payment, the desire to help others is an important consideration. ${ }^{46}$ The gestational carrier and intended parents are often united in their concern for the child and their joy in the process of conception. ${ }^{47}$ Moreover, gestational carriers find that the knowledge that the child they are carrying is that of the intended couple, rather than their own child, strengthens their willingness to participate in the process. ${ }^{48}$ While gestational carriers can experience unfair, insensitive, or dehumanizing treatment, they largely report satisfaction with the experience in the United States. ${ }^{49}$ Within the American context at least, those who become gestational carriers often choose to participate in the surrogacy process because they enjoy the experience of pregnancy, rather than find it intrusive or demeaning. ${ }^{50}$

The second objection to gestational surrogacy concerns the question of whether it is ever appropriate to ask a woman to relinquish the child to whom she has just given birth because of the attachment that arises during pregnancy. With traditional surrogacy, the issue involved the

44. See, e.g., Elizabeth S. Anderson, Is Women's Labor a Commodity?, 19 PHIL. \& PUB. AFF. 71, 75 (1990) (arguing that when women's capacity to carry children "is treated as a commodity, the women who perform it are degraded.”).

45. See Laufer-Ukeles, supra note 1, at 1242.

46. Id.

47. Id.

48. See Scott, supra note 8, at 142; see also Elly TEMAN, BIRThing A Mother: ThE Surrogate Body AND THE PREgnANT SElF 31-68 (2010) (stating that in-depth interviews with gestational surrogates found that they strongly regard the fetus as the child of the intended parents); Hal B. Levine, Gestational Surrogacy: Nature and Culture in Kinship, 42 ETHNOLOGY 179 (Summer 2003).

49. Janice C. Ciccarelli \& Linda J. Beckman, Navigating Rough Waters: An Overview of Psychological Aspects of Surrogacy, 61 J. Soc. IssuEs 21, 31-32 (2005) (finding that most surrogates reported satisfaction with the experience).

50. International surrogacy, however, may involve greater potential for abuse. See Katarina Trimmings \& Paul Beaumont, International Surrogacy Arrangements: An Urgent Need for Legal Regulation at the International Level, 7 J. PRIVATE INT’L LAW 632-33 (2011). 
propriety of the mother's willingness to give up her own child. With gestational surrogacy, the issue is her capacity to do so in light of the emotional attachment that typically attends pregnancy and childbirth. The assumption is that if pregnancy naturally or inevitably produces such feelings, a woman giving birth will naturally and inevitably experience anguish or regret at relinquishing the child. Asking her to do so in advance, before she has actually experienced the emotions involved, is therefore a form of exploitation. ${ }^{51}$ Others feel that women (particularly if they have given birth before) can "control" their emotions, and that they are more likely to do so where they believe they are conferring a gift upon another couple, whom they regard as the child's true parents. $^{52}$ In gestational surrogacy, arguments about women's autonomy and decision-making capacity involve their ability to deal with their own emotions in making an ethically acceptable decision. Empirical studies find, in fact, that gestational carriers do not typically have difficulty relinquishing the child. ${ }^{53}$

A third concern involves the inherent risks of pregnancy and childbirth. This concern gives rise to contentions that asking a woman to undergo such risks for another is a form of exploitation. Even today, a small number of women die in childbirth, even with the best medical care. $^{54}$ Others suffer lifelong side effects from a difficult birth, postpartum medical treatment, postpartum depression, or pregnancyrelated hormonal changes. ${ }^{55}$ The mandatory use of IVF in gestational

51. See, e.g., J. Herbie DiFonzo \& Ruth C. Stern, The Children of Baby M., 39 CAP. U. L. ReV. 345, 356-57 (2011) (indicating that separating from the child is difficult, but not necessarily traumatic).

52. Indeed, empirical studies show that gestational carriers have stronger feelings of emotional attachment to the prospective parents than the child. See Laufer-Ukeles, supra note 1, at 1230-31.

53. See Olga van den Akker, Genetic and Gestational Surrogate Mothers' Experience of Surrogacy, 21 J. REPROD. \& INFANT PsYCHOL. 145, 147 (2003) (noting that some traditional surrogates reported problems relinquishing the child but most did not, and none of the gestational surrogates did). Ironically, some indicate that payment may discourage maternal-fetal attachment during pregnancy. See Hazel Baslington, The Social Organization of Surrogacy: Relinquishing a Baby and the Role of Payment in the Psychological Detachment Process, 7 J. HEALth Psychol 57 (2002).

54. See Maternal \& Child Health Bureau, U.S. Dep’t of Health \& Human Servs., CHILD HEALTH USA 2008-2009 24 (2009), available at http:// mchb.hrsa.gov/publications/pdfs/childhealth200809.pdf; JIAQUAN XU ET AL., CTRS. FOR DISEASE Control \& Prevention, DeAths: Final Data FOR 2007, 58 Nat'l Vital Stat. Rep. May 20, 2010, at 13, available at http://cdc.gov/nchs/data/nvsr/nvsr58/nvsr58_19.pdf (noting that twelve tofifteen women die in childbirth for every 100,000 births).

55. See, e.g., ChildBirth ConNeCtion, VAginal BiRTH AND CESAREAn BiRTH: How Do the RISKS COMPARE? (2006), available at http://www.pqcnc.org/documents/sivbdoc/ sivbeb/8ChildbirthConnectionVaginalBirthandCesareanBirthRiskComparison.pdf (describing the risks that are distinct to vaginal births); Cesarean Procedure Risks, Am. Pregnancy Ass'N, 
surrogacy also increases risks as a gestational carrier must take various hormones to prepare her body for the embryo. ${ }^{56}$ Ethicists question whether prospective surrogates can fully assess these risks, which are hard to determine in advance, and whether these tradeoffs are ethically permissible. That is, while many would accept intended parents' willingness to take physical and financial risks to have a genetically related child, more would question the tradeoffs involved in gestational surrogacy. The gestational carrier is risking her own health and wellbeing to create a child for someone else-typically for payment. The tradeoff between potential health risks and payment is arguably impermissible either because another person (the gestational carrier) is used as a means to an end, ${ }^{57}$ or because of doubt that her consent can ever be truly informed and free of the coercion that comes with payment.

The response to these objections concerning decision-making competency and emotional and physical exploitation depends in part on surrogacy's perceived value. The ability to assist prospective parents to have a genetically related child is itself incalculable. ${ }^{58}$ Accordingly, if intended parents can ethically undertake risks of a surrogate pregnancy, why can't a gestational carrier, motivated at least in part by altruistic concern for the intended parents or child? The question becomes one of informed consent rather than intrinsic objection.

Moreover, payment influences gestational carriers' decisions in varied ways. A given fee, such as the $\$ 10,000$ paid to Mary Beth Whitehead (more like $\$ 20,000$ to $\$ 25,000$ today), ${ }^{59}$ will mean something different to each surrogate depending on the surrogate's socioeconomic status. ${ }^{60}$ Similarly, women vary in their ability to weigh risks and make informed

http://americanpregnancy.org/labor-and-birth/cesarean-risks/ (last visited Mar. 25, 2015) (finding that greater risks are associated with Cesarean procedures); NICETTE JUKELEVICS, UNDERSTANDING THE DANGERS OF CESAREAN BIRTH: MAKING INFORMED DECISIONS 60-65 (2008) (discussing depression and other maternal risks).

56. See, e.g., ASRM Patient Fact Sheet: Risks of In Vitro Fertilization (IVF), AM. SOC’Y FOR REPRODUCTIVE MEDICINE, http://www.asrm.org/FACTSHEET_Risks_of_In_Vitro_Fertilization/ (last visited Mar. 25, 2015).

57. See, e.g., Sonia M. Suter, Giving in to Baby Markets: Regulation Without Prohibition, 16 Mich. J. GENDER \& L. 217, 222 (2009) ("We potentially do harm to ourselves and to human flourishing if we treat something integral to ourselves as a commodity, i.e., as separate and fungible.”).

58. Laufer-Ukeles, supra note 1, at 1224-25.

59. Id. at $1264 \mathrm{n} .244$ (noting that the typical fee today is between $\$ 20,000$ and $\$ 25,000$ ).

60. See I. Glenn Cohen, The Price of Everything, the Value of Nothing: Reframing the Commodification Debate, 117 HARV. L. REV. 689, 689-91 (2003); Laufer-Ukeles, supra note 1, at 1234 (noting that most surrogates are working class; they need the money but are not poor or desperate). 
choices depending on the quality and quantity of information they receive and their individual capacity to evaluate that information. ${ }^{61}$

Taken together, arguments about gestational surrogacy's permissibility are far more contextual than objections to traditional surrogacy. At the core of these arguments is concern about contract structure and payment's role in skewing surrogacy decision-making. The next section will address the role of commercial, for-profit agencies in structuring that decision-making.

\section{COMMERCIALIZATION VERSUS ALTRUISM, AND THE IMPACT OF SURROGACY AGENCIES}

Critics of commodification contrast altruistic and commercial motivations and associate the potential abuse of gestational carriers with the profit motive. Yet, studies of surrogacy in practice find that many of these abuses also occur in altruistic cases. The problems are indicative of surrogacy's growing pains. Creating norms that regularize a new practice, establish ethical standards, and shape parties' expectations takes time and experience. In this section, we contrast the role of commercial agencies with private arrangements in shaping such understandings and identify specific agency practices that contribute to forging an ethical infrastructure for surrogacy agreements. Surrogates' motives and the involvement of a surrogacy agency can profoundly affect the formation and outcome of a surrogacy arrangement.

Consider the case of two gay men, Donald Robinson and Sean Hollingsworth, a married couple who wanted to have a child they would raise together. Donald's sister, Angelia, a childless unmarried woman in her forties, agreed to serve as a gestational carrier. ${ }^{62}$ As part of the agreement, she left her Texas home and went to work for her brother's Manhattan accounting firm. She conceived twins and planned to live permanently near her brother in New Jersey and play a role in the children's lives.

All did not go well. Over the course of the pregnancy, Angelia began to bond with the twins, and she and her brother eventually had a fallingout. $^{63}$ The pregnancy was difficult; Angelia experienced periodic depression and nearly died one month before the due date when her

61. See Laufer-Ukeles, supra note 1, at 1249-50.

62. Stephanie Saul, Building a Baby, With a Few Ground Rules, N.Y. TiMES, Dec. 13, 2009, http://www.nytimes.com/2009/12/13/us/13surrogacy.html?pagewanted=all.

63. Courtney Crandell, Egg Fight, WoRLD, Jan. 11, 2013, http://www.worldmag.com/ 2013/01/egg_fight. 
blood pressure spiked due to pre-eclampsia. Although her brother and his partner took the children home from the hospital, Angelia sued for recognition as their legal mother. As part of the Baby $M$ legacy, New Jersey does not recognize the validity of surrogacy agreements and, absent adoption, treats the woman who gives birth as the legal mother, even without a genetic relationship. ${ }^{64}$ The courts concluded that Angelia was the children's legal mother, and Sean Hollingsworth (as sperm provider) was the legal father. Sean received full legal and physical custody, but Angelia was awarded visitation. Five years after the children's birth, the parties, who agreed on little, were still disputing care issues. ${ }^{65}$

Angelia's case illustrates why those who find surrogacy intrinsically objectionable think it is sensible to ban it outright. The case also embodies the tradeoffs faced by those who do not uniformly oppose surrogacy but fear commercial surrogacy will lead to exploitative, demeaning, or unfair practices. Critics from both perspectives could allege exploitation irrespective of payment. However, exploitation is not inherent within all surrogacy arrangements. If a state takes Washington's approach of allowing altruistic surrogacy-permitting surrogacy but banning payment-the state discourages the practice's growth in-state and encourages its residents to rely on informal or out-of-state surrogacy arrangements, with little ability to shape the practices. If states legalize surrogacy with payment, state regulation and private institutionalization of surrogacy norms may regularize surrogacy relationships and provide participants some protection. For reasons discussed below, no reputable agency today would arrange a surrogacy agreement on the terms Donald and Angelia reached. ${ }^{66}$

In Baby M, many observers disapproved of the commercial entities involved as much, if not more, than surrogacy itself. ${ }^{67}$ There, conflict appeared inevitable and the agency's role in setting up the transaction in spite of the warning signs demonstrated the potentially unsavory nature of commercial agencies. William Stern had gone to much trouble to conceive a genetically related child to ensure continuation of a family line threatened with extermination during the Holocaust. The agency's

64. A.G.R. v. D.R.H., 2009 N.J. Super. Unpub. LEXIS 3250, at*9-10 (N.J. Super. Ct. Ch. Div. Dec. 23, 2009).

65. Ted Sherman, N.J. Gay Couple Fight for Custody of Twin 5-Year-Old Girls, NJ.COM (Dec. 20, 2011), http://www.nj.com/news/index.ssf/2011/12/nj_gay_couple_fight_for_custod.html.

66. See discussion infra at pp. 15-18.

67. See, e.g., Iver Peterson, Fitness Test for Baby M's Mother Unfair, Feminists Say, N.Y. Times, Mar. 20, 1987, at B1. 
pre-conception psychological screening indicated that Mary Beth Whitehead would have difficulty giving up the child, yet the agency still proceeded to use her as a surrogate. ${ }^{68}$ Under these circumstances, both Stern and Whitehead could be expected to bond with the child, yet the agency did not provide either with counseling or assistance after the birth. Banning commercial surrogacy served to eliminate the prospect that profit-motivated agencies would rush to arrange questionable transactions. These bans still allowed parties in need of surrogacy services to canvass family and friends for someone presumably more trustworthy than Mary Beth Whitehead. Yet, there is reason to doubt that altruistic transactions are necessarily happier or less conflicted, or that state bans will necessarily restrain the growth of commercial surrogacy exchanges.

Every state has residents unable to reproduce without gestational surrogacy. To produce a genetically related child in Washington today, these residents have three options. First, they can hire a surrogate out-ofstate. California, which has legalized surrogacy and recognizes intended parents on the child's birth certificate without an adoption proceeding, has a flourishing surrogacy industry attracting prospective parents from around the world. ${ }^{69}$ In addition, international fertility tourism now offers less expensive options. ${ }^{70}$ Shopping for surrogacy-friendly jurisdictions has become a global business. Accordingly, it is unlikely bans on payment will stem its growth. Second, residents can try to enter into their own underground surrogacy agreements, advertising online or responding to others' ads. These informal relationships, however, leave both parties with fewer protections than they would have through authorized transactions. Third, Washington residents interested in surrogacy can try to persuade a friend or family member to give birth without payment-as in Angelia's case. Though these cases sometimes lead to happy conclusions and closer family ties, they can also be exploitative in some of the same ways as commercial surrogacy.

Commercial agencies, in contrast, offer protections that may not have been available at the time of Baby $M$. They have developed policies designed to prevent the conflicts that arose in the Baby $M$ case and between Angelia and Donald. In the first place, no reputable agency

68. Carol Sanger, Developing Markets in Baby-Making: In the Matter of Baby M, 30 HARV. J.L. \& GENDER 67, 90 (2007).

69. Id. at 96 .

70. See, e.g., Sarah Mortazavi, It Takes a Village to Make a Child: Creating Guidelines for International Surrogacy, 100 GEO. L.J. 2249, 2272 (2012) (observing that the cost of surrogacy is significantly less expensive in India than it is in the United States). 
would choose a gestational carrier like Angelia, who was childless and in her forties. Agencies prefer women who have already given birth, partly because it indicates that a carrier can deliver a child without complications, and partly because it provides assurance that she "understands the biological and emotional implications of pregnancy and childbirth." ${ }^{71}$ In an interview discussing the case, the New York Times quoted Dr. James Goldfarb of the Cleveland Clinic, who indicated standard clinical practice when he commented that "[i]f a surrogate has not had a baby before, we won't use her."72 In contrast, parties dependent on altruistic surrogacy may know relatively few women willing to be gestational carriers, and may not have the luxury of looking for more suitable candidates.

Moreover, arm's length practices provide a measure of protection for both intended parents and surrogates. The fertility clinic involved in the Robinson case had offered psychological screening, but the parties refused; ${ }^{73}$ if the surrogate were a stranger, the clinic would have been more likely to have insisted on the screening and the intended parents would have been more likely to accept. ${ }^{74}$ Angelia felt pressure from her brother to agree, and the lack of options may have heightened the pressure on both parties to proceed. ${ }^{75}$ In addition, the brother and sister entered into arrangements that strangers in a contractual relationship are unlikely to do: Angelia sold her Texas home where she had lived all her life, accepted a job with Donald's firm in New York, used her own assets and some of her brother's to set up a bed and breakfast, and became dependent on him financially. ${ }^{76}$ After the birth—and the rupture in her relationship with her brother - she had no home, no savings, no job, and no access to the children she had planned to help raise. She responded by rediscovering her Baptist faith and denouncing both surrogacy and homosexuality, complicating the relationship with her brother and his spouse. ${ }^{77}$

71. See Saul, supra note 62. They also prefer gestational carriers who, unlike Mary Beth Whitehead, have no genetic tie to the child. See also Laufer-Ukeles, supra note 1, at 1260 (noting that more than ninety-five percent of surrogates carry children to whom they are not genetically related).

72. See Saul, supra note 62.

73. Id.

74. See, e.g., Laufer-Ukeles, supra note 1, at 1262 (noting that psychological screening is matter of common practice even where not mandated by state law).

75. Harold Cassidy, The Surrogate Uterus: The AGR Case and Melissa Brisman, PUBLIC DisCOURSE, (Sept. 7, 2012), http://www.thepublicdiscourse.com/2012/09/6216/.

76. Id.

77. Crandell, supra note 63. 
By contrast, agencies often structure the relationship to separate surrogacy's commercial and altruistic parts. Agencies typically require that the intended parties make payments in advance. The agency then distributes the payments to the surrogate when required conditions have been met. ${ }^{78}$ In addition, agencies may insist that the surrogate have separate legal representation to increase chances a contract will be enforced; Angelia instead waived the right to separate counsel. ${ }^{79}$ Even if the contract is of questionable enforceability, independent counsel may review matters such as the agreement's binding force (void in New Jersey), the parties' plans for an abortion from birth defects or other contingencies, the need for an adoption to transfer legal parentage, the carrier's ability to change her mind post-birth (an uncertain matter in New Jersey at that time), and any anticipated post-birth contact with the child. Angelia's lawyer reported that she moved to New Jersey in part to have a continuing relationship with the children, but she signed an agreement that severed her parental status and made access to the children dependent on her brother and his spouse's goodwill. As brother and sister, Donald and Angelia had expectations that Angelia's involvement with the twins would continue, but these expectations, at least on Angelia's part, may well have gone beyond the conventional role of an "aunt." Thorough exploration of the agreement and the parties' post-birth expectations might have persuaded them that this sister-as-surrogate arrangement was not a good idea, or could have produced more realistic plans and expectations.

Moreover, processes of socialization may allow parties to surrogacy arrangements to traverse well-trodden paths instead of hacking their own way haphazardly through the experience. Many of the practices surrounding pregnancy, marriage, and childbirth have been "institutionalized" in that social norms define parties' expected behavior within the institutions of marriage and legal parenthood. ${ }^{80}$ Andrew Cherlin, for example, has argued that marriage once served to socialize young people into adulthood through the assumption of predictable, gendered roles. ${ }^{81}$ Remarriage, the stepparent role, and same-sex relationships did not have the same "institutionalization" function

78. See, e.g., Johnson v. Calvert, 851 P.2d 776, 778 (Cal. 1993) (noting in that case that the surrogate was paid in installments over the course of the pregnancy, with the final installment scheduled for six weeks after birth).

79. Cassidy, supra note 75.

80. See, e.g., Andrew Cherlin, The Deinstitutionalization of American Marriage, $66 \mathrm{~J}$. MARRIAGE \& FAM. 848 (2004).

81. Id. at $848-849$. 
because role expectations were far less detailed or uniform. ${ }^{82}$

The relationship between Sean, Donald, and Angelia was not "institutionalized" in any sense. It is not too much of a stretch to say that their collaborative reproduction plan required making it up as they went along. Both surrogate and same-sex reproduction, after all, are relatively new. Over the time period from the twins' conception to the custody resolution five years post-birth, Sean and Donald went from a relationship that could not receive legal recognition in most states, to marriage in California, to repeal of the right to marry (that nonetheless did not invalidate their particular union), to recognition of their California marriage in New York (where Donald and Angelia worked but not in New Jersey where they lived). The legal status of gestational surrogacy and the parties' subsequent parental status also shifted during the same time period-neither New York nor New Jersey adopted comprehensive legislation addressing the issue. ${ }^{83}$ As a result, the litigation between the parties addressed issues that had not been resolved under New Jersey law at the time the parties entered into their initial agreement. ${ }^{84}$

If surrogacy becomes common, particularly for gay couples, its associated roles may become more routinized and, with shared expectations, more institutionalized. This is more likely to happen, however, if commercial agencies play a role in the process. After all, a quarter century after Baby $M$, the agencies, which were in their infancy at the time of the case, largely responded by moving out of New Jersey. ${ }^{85}$ The question for the future is what role payment-and attorneys and commercial agencies-plays in the creation of appropriate ethical understandings for the development of new forms of reproduction.

\section{REPEAT PLAYERS, COMMERCIAL AGENCIES, AND ETHICAL CODES}

Ethical codes-and the institutionalization of family norms-come from the formalization of shared experiences. For that to happen,

\footnotetext{
82. Id. at 848 .

83. Scott, supra note 8 , at 120 .

84. See generally, A.G.R. v. D.R.H., 2009 N.J. Super. Unpub. LEXIS 3250 (N.J. Super. Ct. Ch. Div. Dec. 23, 2009).

85. See Lawrence Van Gelder, Noel Keane, 58, Lawyer in Surrogate Mother Cases, is Dead, N.Y. TIMES, Jan. 28, 1997, http://www.nytimes.com/1997/01/28/nyregion/noel-keane-58-lawyer-insurrogate-mother-cases-is-dead.html (stating that Keane, the lawyer who arranged the Baby M surrogacy, maintained offices elsewhere, such as in Indianapolis, Indiana).
} 
practices need to be visible and opinion leaders such as legislators, courts, religious figures, and professionals need to shape and fix in place appropriate understandings. Repeat players in surrogacy arrangements can anticipate what can and will go wrong and design procedures accordingly. Some arrangements that may feel appropriate in a conflictfree relationship will appear unfair or even exploitative in the event of a dispute. Donald's willingness to provide Angelia with a job and help to establish her bed and breakfast seems well-meaning, even generous, in the context of a collaborative brother-sister relationship, but oppressive in encouraging Angelia to become financially dependent and therefore vulnerable. In this section, we argue that commercial agencies, subject to appropriate regulation and oversight, are more likely to protect the parties involved in a surrogacy arrangement than laws that restrict surrogacy to altruistic exchanges.

Commercial surrogacy agencies, through their broker role, may "lock in” practices that help surrogacy operate more smoothly, particularly in jurisdictions without comprehensive regulation. This does not always mean that agencies adopt best practices or that they act against selfinterest. Instead, it simply means that the presence of commercial actors in the surrogacy process changes the dynamic in predictable ways. We discuss four of those ways below.

First, agencies alter supply and demand. Donald and Angelia may have each felt pressure to reach an agreement if both believed it was the only way for Donald to have a child with his partner. An agency recruiting many possible gestational carriers would have increased the supply. Given other possible surrogates, Angelia may have felt freer to press Donald about terms of their agreement, and Donald may have thought twice about whether to use his sister. Alternatively, after examining an arm's length arrangement with another carrier, they may have agreed on different terms or evolved a different understanding of the arrangement.

Second, agencies act on the basis of past experience. Clinic practices reflect institutional memory of past cases, particularly cases that go wrong. Fertility clinics, surrogacy agencies, and lawyers tend to incorporate lessons gleaned from past experiences into new procedures. For example, in recruiting surrogates, agencies often require that prospective gestational carriers be over twenty-one and under forty-one; have no sexually transmitted diseases, cancer, substance abuse, or other disqualifying medical conditions; be financially secure; have a supportive environment; and be capable of handling pregnancy's 
physical and emotional issues. ${ }^{86}$ Many clinics also will not work with carriers who have not given birth ${ }^{87}$ and require psychological screening; jurisdictions that regulate surrogacy often mandate such evaluations. ${ }^{88}$

These requirements explain much of what went wrong in Angelia Robinson's case. Her age may have increased her susceptibility to pregnancy complications. Selling her house, quitting her job, and moving to New Jersey made her financially vulnerable. Agencies rule out those who are too financially desperate, which also tends to limit claims of exploitation. ${ }^{89}$ They also prefer gestational carriers who have "a supportive environment," which often means a significant other, children, friends, and family on whom they can rely-apart from the intended parents. Carriers who already have children not only know what to expect, but are less likely to regard surrogacy as their only opportunity to have a child, as Angelia did. These practices help select surrogates who are more likely to surrender the child at birth-and limit the potential that the surrogate will be exploited, treated unfairly, or physically or emotionally endangered by the pregnancy.

Third, agencies assist parties in forming contracts and ensure independent representation. Even in a state like New Jersey where surrogacy contracts are unenforceable, working through an agreement may help parties understand what they are likely to face and provide a framework for future decisions. As one lawyer observed, "[t]he act of setting down the intentions, expectations and goals of the parties will diminish the chance of later conflict or disappointment." 90

Courts, moreover, may be inclined to hold those who profit from surrogacy arrangements to a duty to look out for the interests of both parties. Two individuals - an attorney and a surrogacy broker - who had arranged a surrogacy arrangement were held liable when the child was born with severe birth defects that might have been prevented had the father been properly screened. The court held: "This . . . affirmative duty of protection, marked by heightened diligence, arises out of a special relationship because the defendants engaged in the surrogacy business

86. Stephen L. Corson et al., Gestational Carrier Pregnancy, 69 FerTiLity \& StERILITY 670, 671 (1998).

87. See Ciccarelli \& Beckman, supra note 49, at 34.

88. See, e.g., Charles P. Kindregan, Jr. \& Steven H. Snyder, Clarifying the Law of ART: The New American Bar Association Model Act Governing Assisted Reproductive Technology, 42 FAM. L.Q. 203, 216 (2008) (suggesting legislation that mandates psychological consultations).

89. See Laufer-Ukeles, supra note 1, at 1264.

90. William S. Singer, Exploring New Terrain: Assisted Reproductive Technology (ART), The Law and Ethics, 8 RUTGERS J.L. \& PUB. POL’y 918, 928 (2011). 
and expected to profit thereby." 91 Attorneys have a duty to design and administer a program that would protect the participants from foreseeable harm. ${ }^{92}$ Federal and state regulation can also address health and other standards ${ }^{93}$ and, if appropriate, limit contractual waivers of liability. The formalization and professionalization of the process means that these professionals are likely to be held responsible for things that go awry, providing incentives for anticipating — and avoiding - potential sources of liability.

Of course, including lawyers and formal contracts also involves opportunities for one-sided bargains. ${ }^{94}$ Angelia Robinson did sign a contract, albeit one that misstated her options under New Jersey law, and did so without legal representation. Lawyers often encourage parties to agree to provisions that may not be legally enforceable. Such provisions are inappropriate where they mislead, but they may also create a framework to deal with possible contingencies. For example, while no court will enforce a provision compelling an abortion over the gestational carrier's objection, such a provision may encourage parties to contemplate what to do if a fetus has birth defects. Some surrogacy contracts, for example, now include provisions that provide for selective reduction of multiples, but they may also limit the provision to higher order multiples such as triplets. The objection to selective reduction of twins may reflect agency preferences, emerging norms in the field, or a desire to routinize a likely wrenching decision. Whatever the motivation, the contract provisions helps shape expectations before the issue arises.

Routinizing the contract process requires attention to three distinct circumstances: (a) where contracts are enforceable, separate representation, particularly for the party with less bargaining power, is critical; ${ }^{95}$ (b) where provisions may not be enforceable, they still lock in agreements about how to handle foreseeable problems, and they should be based on complete and accurate information; and (c) where they insulate commercial actors from liability, they should be subject to scrutiny. Nonetheless, the inclusion of professional, experienced parties who can realistically anticipate, explain, and plan for potential

\footnotetext{
91. Stiver v. Parker, 975 F.2d 261, 268 (6th Cir. 1992).

92. Id. at 268.

93. Lauren Gill, Who's Your Daddy? Defining Paternity Rights in the Context of Free, Private Donation, 54 WM. \& MARY L. REV. 1715, 1731-34 (2013) (reviewing health regulations).

94. See, e.g., Catherine London, Advancing a Surrogate-Focused Model of Gestational Surrogacy Contracts, 18 CARDOZO J.L. \& GENDER 391, 412-13 (2012).

95. See, e.g., Jill Elaine Hasday, Intimacy and Economic Exchange, 119 HARV. L. REV. 491, 526 (2005) (explaining the relationship between independent counsel and informed consent).
} 
complications is an advantage.

Fourth, agencies restructure surrogacy's commodification and contractual dimensions. Much of the objection to surrogacy comes from the association between reproduction as an intimate activity and payment, resulting in commodification. Yet, many of those who have expressed concern about commodification do not necessarily wish to ban surrogacy, and recognize that some compensation for pregnancy's intrusiveness, expense, inconvenience, and discomfort is appropriate. ${ }^{96}$ One response is to consider how surrogacy's business aspects, including payment, can be structured to minimize its dehumanizing aspects. Such measures include:

a) Fixed prices. Many parties find haggling over price unseemly, particularly when the result creates higher prices for more favored groups along lines such as race, nationality, class, and so on. The Association of Reproductive Medicine (ASRM) has, for example, tried to standardize payments to egg donors. ${ }^{97}$ The creation of a standardized price may constrain some of surrogacy's commercialized aspects. As Pamela Laufer-Ukeles observes, "capping the price reflects the desire to ensure that surrogacy is not fully marketized but rather appreciated for its dual function of creating intimate and monetary relationships."98

b) Staggered Payments. One of the differences between Baby $M$ and Calvert involved the difference between a lump sum payment upon birth versus staggered payments over the pregnancy term. Whereas a lump sum payment seems closer to baby-selling, staggered payments more closely resemble compensation for services. Moreover, initial payments acknowledge the surrogate's assumption of a responsibility to the intended parents from the beginning and mutual involvement in the pregnancy.

c) Third party brokers. When third parties are not involved, the intended parents and the carrier handle financial matters directly. Donald

96. See Laufer-Ukeles, supra note 1, at 1247; Mary Anne Case, Pets or Meat, 80 CHI.-KenT L. REV. 1129, 1144-45 (2005); Michele Goodwin, Relational Markets in Intimate Goods, 44 TULSA L. ReV. 803, 810 (2009); Kimberly D. Krawiec, A Woman's Worth, 88 N.C. L. REV. 1739, 1757 (2010); Jennifer L. Watson, Growing a Baby for Sale or Merely Renting a Womb: Should Surrogate Mothers Be Compensated for Their Services?, 6 WHITTIER J. CHILD \& FAM. ADVOC. 529, 544, 545 (2007); Lori B. Andrews, Beyond Doctrinal Boundaries: A Legal Framework for Surrogate Motherhood, 81 VA. L. REV. 2343, 2349-50 (1995) (observing that she interviewed women who had acted as surrogate mothers expecting to find exploitation of women who had agreed to become surrogates because of the money involved and, instead, concluded that the potential risks are "rashly speculative and bear no relationship to the arrangements as they currently exist.”); Sanger, supra note 68 , at $77-78$.

97. But see Krawiec, supra note 96, at 1759-69.

98. Laufer-Ukeles, supra note 1, at 1264. 
Robinson, for example, hired his sister, commingled the proceeds from her home's sale with his own funds in purchasing and renovating the bed and breakfast, and paid for the pregnancy's medical costs. These activities created numerous individual transactions that could lead to bad will. Even the act of writing a check, particularly if the amount is not fixed in advance, reminds the parties of the commercial nature of their relationship, creating opportunities for potential disputes or simply discomfort. In contrast, most agencies arrange for intended parents to submit payments to the agency, which then disperses payments to the surrogate. This allows the surrogate and the intended parents to interact without having to discuss finances.

d) Acknowledgment of the non-pecuniary aspects of the surrogacy relationship. As Laufer-Ukeles indicates, most studies find that altruistic motivations are important to women who choose to be gestational carriers, and their relationship with the intended parents greatly influences their attitudes toward the experience. ${ }^{99}$ At the same time, intended parents sometimes resent the carrier's ability to produce a child they cannot and may want to micromanage the carrier's pregnancy, ${ }^{100}$ dictating diet, exercise, and medications, or prohibiting alcohol, caffeine, heavy lifting, sex, and travel. Third party professionals can be useful in structuring these relationships. They can inform the parties about the current medical opinion on such matters as use of caffeine (now thought to be less harmful than a few years ago), routine exam frequency, or the risk of travel close to the due date. ${ }^{101}$ Third party professionals help to create reasonable expectations by drafting contracts ${ }^{102}$ that shape and clearly articulate understandings about factors such as diet, health care, alcohol, sex, travel, participation in prenatal exams, delivery, and postbirth contact. In addition, they counsel intended parents ${ }^{103}$ about the nature of the relationships and appropriate etiquette. Finally, third party professionals provide opportunities for the gestational carrier and the intended parents to interact outside of formal or stressful events such as

\footnotetext{
99. Id. at 1233 .

100. See, e.g., London, supra note 94 , at 413.

101. See, e.g., Jennifer Damelio \& Kelly Sorensen, Enhancing Autonomy in Paid Surrogacy, 22 BIOETHICS 269, 269-70, 275-76 (2008) (recommending counseling as a way to promote greater autonomy and informed consent).

102. London, supra note 94, at 413.

103. See, e.g., Pamela Laufer-Ukeles, Reproductive Choices and Informed Consent: Fetal Interests, Women's Identity, and Relational Autonomy, 37 AM. J.L. \& MED. 567, 616-17 (2011) (suggesting informational counseling sessions as opposed to psychological screenings in the context of reproductive choices); Ciccarelli \& Beckman, supra note 49, at 34, 39 (evaluating effectiveness of counseling).
} 
contract preparation or delivery of the child.

In short, the inclusion of agencies, as repeat players with a stake in the smooth execution of surrogacy arrangements, helps to normalize them. The agencies should screen out the most vulnerable participants, shape the understandings of the parties in ways that minimize future conflicts, provide professional legal and psychological assistance in dealing with unexpected events, and structure the parties' interactions in ways that increase the likelihood of success and satisfaction. These profit-driven agencies are, of course, more likely to take greater care if their actions are visible and they may be called to account. Despite their potential drawbacks, they still offer greater hope for the standardization of appropriate norms than individually arranged transactions, whether altruistic ones taking place with friends and family or foreign sojourns in search of available services.

\section{CONCLUSION}

The surrogacy process, like the creation of any new family, involves bringing people together who may have different assumptions, experiences, and values. Institutions instantiate shared expectations and norms about events, whether they are routine or more exotic undertakings. Legal mandates and private contracts can encourage surrogacy participants to develop shared expectations about the experience, but are unlikely to occur without visibility, transparency, and the involvement of third party professionals.

It should be noted that including these professionals can be expensive. Indeed, the expense of assisted reproduction generally and surrogacy, in particular, is fueling international medical tourism, which will make it that much harder either to enforce surrogacy bans or to develop appropriate, equitable, and non-exploitative practices. ${ }^{104}$ In this context, allowing commercial surrogacy in the United States, with appropriate safeguards, may contribute to the development of established practices that govern surrogacy globally. When surrogacy arrangements include agencies and professionals with a stake in making these relationships work, these arrangements safeguard the respect and dignity of both surrogates and intended parents. 